\title{
Dehydrocostus Lactone Suppresses the Expression of iNOS Induced by TLR Agonists
}

\author{
Su Yeon Kim*, Sunghye Heo*, Seung Han Kim*, Minji Kwon*, \\ Sin-Aye Park ${ }^{* *}$ and Hyung-Sun Youn ${ }^{\dagger, * *}$ \\ Department of Biomedical Laboratory Science, College of Medical Sciences, \\ SoonChunHyang University, Chungnam, Asan 31538, Korea
}

Toll-like receptors (TLRs) are one of the families of pattern recognition receptors (PRR) to recognize pathogenassociated molecular patterns (PAMPs). PAMPs stimulate TLRs to initiate specific immunoactivity. The activation of TLRs signaling leads to the expression of pro-inflammatory gene products such as cytokines and inducible nitric oxide synthase (iNOS). To evaluate the therapeutic potential of dehydrocostus lactone (DHL), which is a natural sesquiterpene lactone derived from various medicinal plants, iNOS expression induced by LPS (TLR4 agonist), MALP-2 (TLR2 and TLR6 agonist), or Poly[I:C] (TLR3 agonist) were examined. DHL suppressed the iNOS expression induced by LPS, MALP-2, or Poly[I:C]. DHL also inhibited nitrite production induced by LPS, MALP-2, or Poly[I:C]. These results suggest that DHL can modulate TLRs signaling pathways resulting in anti-inflammatory effect.

Key Words: Dehydrocostus lactone; Inducible nitric oxide synthase; TLR; Inflammation; LPS

\section{서 론}

만성 염증(chronic inflammation)은 박테리아나 바이러스 감염과 같은 외부 자극에 반응하여 유도되는 병리생리학 (pathophysiology)적인 현상으로, inducible nitric oxide synthase (iNOS)가 염증 유발에 중요한 기능을 하는 것으로 보고되어 있다(Murakami and Ohigashi, 2007). 산화질소(NO) 는 기체 상태의 간단한 무기 분자로, 세포 내에서 전달자 의 기능을 가지고 있다. $\mathrm{NO}$ 는 선천성 면역체계의 유도를 위해서 중요한 역할을 한다(Lowenstein and Padalko, 2004). 활성화된 대식세포는 $\mathrm{NO}$ 를 포함한 다양한 분자들을 방출 함으로써 병원체 복제를 억제한다. NO의 합성은 아미노산 L-arginine을 L-citrulline으로 변환하여, nitric oxide synthase
(NOS)로 알려진 효소에 의해 매개된다. NOS는 neuronal $\mathrm{NOS}$ (nNOS), endothelial NOS (eNOS), 그리고 면역반응에 관여하는 inducible NOS (iNOS)의 세 가지 동위효소를 가 지고 있다(Knowles, 1996). nNOS와 eNOS는 일정하게 발현 되는 구성(constitutive) 효소이며, 이와는 대조적으로 iNOS 는 건강한 상태에서는 발현되지 않고, 오히려 면역반응이 나 미생물 자극에 의한 세포 자극에 따른 염증유도 조건 에서 발현한다(Knowles, 1996).

톨(Toll) 유전자는 처음에 초파리(Drosophila)에서 발견되 었고, 배복성의(dorsoventral) 배아 발달과 선천성 면역 기 능을 중재하기 위하여 발견되었다(Anderson et al., 1985). 1997년 인간에서 Toll이 발견되어 초파리 Toll과 구별하기 위하여 Toll-like receptor (TLR)라 명명되었다(Medzhitov et al., 1997). TLR4가 최초로 발견되었으며, 현재 13 개의 TLRs

Received: July 4, 2019 / Revised: August 8, 2019 / Accepted: August 17, 2019

*Ungraduate student, ${ }^{* *}$ Professor.

† Corresponding author: Hyung-Sun Youn. Department of Biomedical Laboratory Science, College of Medical Sciences, SoonChunHyang University, Soonchunhyang-Ro 22, Shinchang-Myun, Asan-Si, Chungnam 31538, Korea. Tel: +82-41-530-3086, Fax: +82-41-530-3085, e-mail: hyoun@sch.ac.kr (C) The Korean Society for Biomedical Laboratory Sciences. All rights reserved.

(c) This is an Open Access article distributed under the terms of the Creative Commons Attribution Non-Commercial License (http://creativecommons.org/licenses/by-nc/3.0/) which permits unrestricted non-commercial use, distribution, and reproduction in any medium, provided the original work is properly cited. 


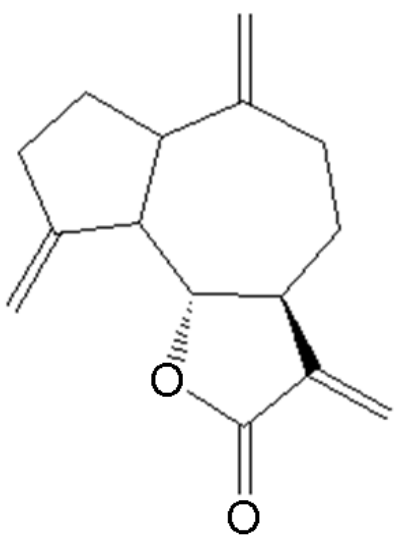

Dehydrocostous lactone

Fig. 1. The structure of dehydrocostus lactone (DHL).

가 인간과 마우스에서 발견되었다(Poltorak et al., 1998). TLR1-10은 인간에서 발견되었으며, TLR1-9과 TLR11-13은 마우스에서 발견되었다. TLRs 자극제(agonist)는 특별한 면 역반응을 유도하기 위하여 TLRs를 자극하는 pathogenassociated molecular patterns (PAMPs)이다. 가장 많이 연구 된 TLRs 자극제는 lipopolysaccharide (LPS; TLR4 agonist), lipopeptides(TLR1, TLR2, 그리고 TLR6 agonists), flagellin (TLR5 agonist), single stranded RNA(TLR7 and TLR8 agonist), double stranded (ds) RNA (TLR3 agonist), 그리고 DNA containing the CpG motif (TLR9 agonist)이다(Medzhitov, 2001). 최근의 연구에 의하면 스트레스를 받거나 죽은 세포에서 방출되는 heat shock proteins (HSP; TLR2와 TLR4)과 high mobility group box 1 (HMGB1; TLR2와 TLR4) 또한 중요 한 TLRs 자극제로 알려졌다(Asea et al., 2002; Kepp et al., 2011). TLRs 자극제가 그들의 수용체에 결합하면 둘 중 하나인, myeloid differential factor 88 (MyD88)- 또는 TIR domain-containing adaptor inducing interferon- $\beta$ (TRIF)를 의 지한 신호전달체계를 유도한다. MyD88를 의지한 신호전 달체계는 NF-kB, mitogen-activated protein kinase (MAPK)나 cytokines, chemokines, 그리고 cytosolic 효소의 전사 활성화 를 유도하는 반면에 TRIF-dependent 신호전달체계는 늦은 $\mathrm{NF}-\kappa \mathrm{B}$ 나 interferon regulatory factor 3 (IRF3)의 활성을 유도 한다(Kawai and Akira, 2010). 이러한 전사인자의 활성화는 $\mathrm{iNOS}$ 와 같은 염증 관련 유전자의 발현을 증가시켜 여러 질병을 초래하게 된다(Akira and Takeda, 2004). 그러므로 TLRs의 신호전달체계 조절은 염증반응이나 다양한 질병 들을 예방할 수 있는 것이다.
Dehydrocostus lactone (DHL)은 (Fig. 1) Inula helenium $L$. and Saussurea lappa와 같은 국화과 식물로부터 추출되는 sesquiterpene lactone이다. 여러 연구에 의하면 DHL은 항염 증(Cho et al., 2000), 항괴양(Yoshikawa et al., 1993), 항암(Ko et al., 2004) 및 면역조절(Pandey et al., 2007) 기능을 포함 한 여러 가지 약리학적 효능을 가지고 있는 것으로 알려 져 있다. 하지만 이러한 $\mathrm{DHL}$ 의 약리학적 효능에 대한 분 자적 작용기전은 아직까지 완전히 밝혀져 있지 않다. 그 러므로 본 연구에서는 DHL이 TLRs의 신호전달체계를 조 절함으로써 $\mathrm{iNOS}$ 를 포함한 염증반응에 미치는 영향에 대 해 알아보고자 한다.

\section{재료 및 방법}

재료

실험에 사용한 LPS (lipopolysaccharide; TLR4 agonist)는 List Biological Lab (San Jose, CA, USA)으로부터, MALP-2 (macrophage-activating lipopeptide of $2 \mathrm{kDa}$; TLR2와 6 agonist)는 Alexis Biochemical (San Diego, CA, USA)로부터, Polyriboinosinic polyribocytidylic acid (poly[I:C]; TLR3 agonist) 는 Amersham Biosciences (Piscataway, NJ, USA)로부터 구 입하였다. iNOS 항체는 BD Biosciences (San Jose, CA, USA) 로부터, $\beta$-actin 항체는 Santa Cruz Biotechnology (Santa Cruz, CA, USA)로부터 구입하였다. Dehydrocostus lactone 은 Selleckchem (Houston, TX, USA)으로부터 구입하였다. 그 밖의 다른 시약들은 특별한 언급이 없는 한 SigmaAldrich로부터 구입하였다.

\section{세포 배양}

RAW264.7 세포들은(murine monocytic cells, ATCC TIB-71) Dulbecco's modified Eagle's medium (DMEM) (10\% (v/v) FBS, 100 units $/ \mathrm{mL}$ Penicillin, $100 \mu \mathrm{g} / \mathrm{mL}$ streptomycin)을 사용하여 $5 \% \mathrm{CO}_{2} / \mathrm{air}, 37^{\circ} \mathrm{C}$ 에서 배양하였다.

\section{Plasmid}

iNOS-luciferase plasmid는 Daniel Hwang (University of California, Davis, CA, USA)으로부터 제공받았다. Heat shock protein (HSP) 70- $\beta$-galactosidase plasmid는 R. Modlin (University of California, Los Angeles, CA, USA)으로부터 제공받 았다. 위의 모든 DNA는 EndoFree Plasmid Maxi kit (Qiagen, Valencia, CA, USA)을 사용하여 준비되었다. 
Cell viability test

3-(4,5-dimethylthiazol-2-yl)-5(3-carboxymethoxyphenyl)-2(4-sulfophenyl)-2H-tetrazolium (MTT) 사용하여 세포 생존율 을 측정하였다(Kim et al., 2018b). RAW264.7 세포를 96 well plate에 분주하고 4시간 동안 MTT 약물을 처리한 후, well plate에 CellTiter 96 AQueous One Solution Reagent (Promega, Madison, WI, USA)를 첨가하였으며, 4시간 동안 배양하였 다. 그 후 96 well plate reader를 사용하여 $490 \mathrm{~nm}$ 에서 흡광 도를 측정하여 세포 생존율을 측정하였다.

\section{Transfection과 luciferase를 이용한 유전자 발현 분석 (luciferase reporter gene assay)}

iNOS 유전자 발현은 luciferase assay를 사용하여 분석 하였다(Kim et al., 2018a). RAW264.7 세포를 48 well plates 에 균등 분주하여 배양하였다, 하루 뒤에 50 60\% 정도 세포증식을 보일 때, iNOS-luciferase plasmid와 HSP70- $\beta$ galactosidase plasmid는 Superfect transfection 시약(Qiagen, Valencia, CA, USA)을 사용하여 세포 안으로 transfection 시켰다. 10 또는 $20 \mu \mathrm{M} \mathrm{DHL}$ 을 pretreat한 후 1시간 동안 배양하였다. 그리고 agonist를 처리한 후 8시간 동안 배양 하였다. Luciferase assay system (Promega, Madison, WI, USA) 을 사용하여 luciferase의 활성을 luminometer (Berthold, BadWildbad, Germany)로 측정하였으며, $\beta$-galactosidase의 활성 화 정도를 확인하여 표준화시켰다.

\section{Western blotting}

TLR agonist와 DHL을 처리한 세포로부터 추출된 단백 질들은 SDS-PAGE (sodium dodecyl sulfate-polyacrylamide gel electrophoresis)에서 크기에 따라 분리되었다. 이후 분 리된 단백질들은 immunoblotting 방법을 사용하여 polyvinylidene difluoride membrane으로 이동되었다(Youn et al., 2006a; Youn et al., 2006b). Membrane은 0.1\% Tween 20와 $5 \%$ 탈지 건조된 우유를 포함하고 있는 phosphate-buffered saline에서 blocking 되었다. Membrane에 1차 항체(iNOS 또는 $\beta$-actin)를 붙이고 horseradish peroxidase가 결합된 2차 항체를 붙인 후, iNtRON western blot detection system (Seongnam, Gyeonggi-do, Korea)을 사용하여 단백질의 발현 을 확인하였다.

\section{Nitrite assay}

$\mathrm{DHL}$ 의 $\mathrm{iNOS}$ 에 대한 효과를 측정하기 위하여 $\mathrm{iNOS}$ 에

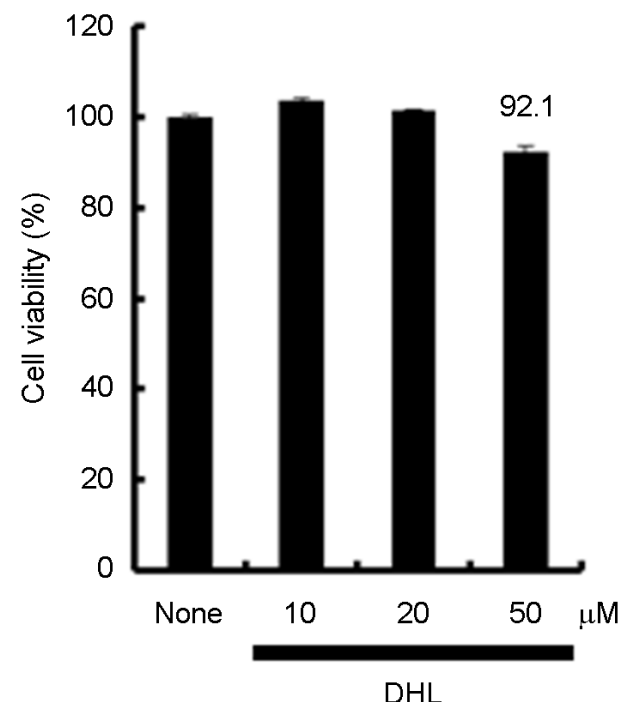

Fig. 2. Cells viability assay of dehydrocostus lactone. RAW264.7 cells were treated with DHL $(10,20,50 \mu \mathrm{M})$ for $4 \mathrm{~h}$. Twenty microliters of the CellTiter $96 \mathrm{AQ}_{\text {ueous }}$ One Solution Reagent was added directly to culture wells. The plate was incubated at $37^{\circ} \mathrm{C}$ for $4 \mathrm{~h}$ in a humidified $5 \% \mathrm{CO}_{2}$ atmosphere. The absorbance was recorded at $490 \mathrm{~nm}$ with a 96-well plate reader. Veh, vehicle; DHL, dehydrocostus lactone.

의해서 만들어지는 nitrite $\left(\mathrm{NO}_{2}\right)$ 를 측정하였다 $(\mathrm{Lim}$ et al., 2008). NO는 매우 불안정한 물질로 측정이 쉽지 않아서 대신 $\mathrm{NO}$ 의 산화 과정에 의해서 만들어지는 nitrite $\left(\mathrm{NO}_{2}\right)$ 를 대신 측정하였다. 세포 배양 well plate의 상층액에 분주기 를 사용하여 Griess reagent를 첨가하였으며, plate reader를 사용하여 $570 \mathrm{~nm}$ 에서 흡광도를 측정하였다. 표준 물질로 sodium nitrite를 사용하였다.

\section{데이타 분석}

각각의 데이타 값은 서로 다른 세 개의 값을 정량하여 Student's $t$-test로 얻어졌으며, mean \pm standard error mean (SEM)으로 표현되었다.

\section{결과 및 고찰}

\section{Dehydrocostus lactone의 세포 독성 효과}

첫 번째로, RAW264.7 세포에서 DHL의 독성 효과를 평 가하기 위해 MTT assay를 사용하여 세포 생존율을 측정 하였다. 세포들은 DHL $20 \mu \mathrm{M}$ 의 농도에서 $100.0 \%, 50 \mu \mathrm{M}$ 농도에서 $92.1 \%$ 생존율을 보였다(Fig. 2). 이후의 모든 실 험은 DHL $20 \mu \mathrm{M}$ 농도까지 사용하였다. 
Dehydrocostus lactone은 TLR agonists에 의해 유도 된 iNOS 발현을 억제

다음 실험으로 DHL이 여러 TLR agonists에 의해서 유 도된 iNOS에 어떠한 영향을 미치는지 알아보았다. DHL 은 LPS (TLR4 agonist), MALP-2 (TLR2와 TLR6 agonist), 그리고 Poly[I:C] (TLR3 agonist)에 의해 유도된 iNOS의 과 발현을 억제하는 것을 iNOS-luciferase assay를 활용하여 측정하였다(Figs. 3A-C). 또한 DHL이 LPS, MALP-2, 그리 고 Poly[I:C]에 의해 유도된 iNOS 단백질의 과발현을 저 해하는 것을 Western blotting 방법을 통하여 확인하였다 (Figs. 4A-C). 또한 DHL이 iNOS의 생성물인 nitrite $\left(\mathrm{NO}_{2}\right)$
의 생성에 어떠한 영향을 미치는지 확인해 보았다. Nitrite $\left(\mathrm{NO}_{2}\right)$ 는 $\mathrm{NO}$ 의 산화 과정에 의해서 만들어지는 $\mathrm{NO}$ 의 생 리학적인 저장 풀로 여겨진다. DHL은 LPS, MALP-2, 그리 고 Poly[I:C]에 의해서 유도된 nitrite $\left(\mathrm{NO}_{2}\right)$ 의 생성을 억제 하였다(Figs. 5A-C). 이러한 결과들을 종합해 보면 DHL은 TLR 자극제에 의해 유도되는 $\mathrm{iNOS}$ 의 발현과 그 생성물 인 nitrite $\left(\mathrm{NO}_{2}\right)$ 의 생성을 조절하여 염증반응을 조절할 수 있다는 것을 예측할 수 있다.

$\mathrm{NOS}$ 는 $\mathrm{nNOS}$, eNOS, iNOS 등 세개의 이성질체로 구 성되어 있다(Lind et al., 2017). nNOS는 중추신경계와 말초 신경계 모두의 신경조직에서 $\mathrm{NO}$ 를 생성한다(Lind et al., 2017). nNOS는 또한 세포 의사소통에서 역할을 수행하며
A

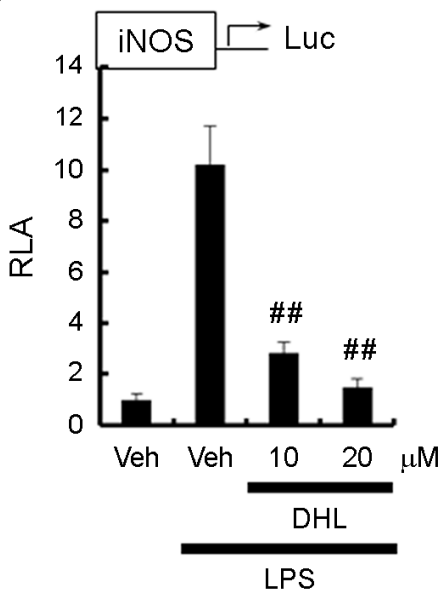

B

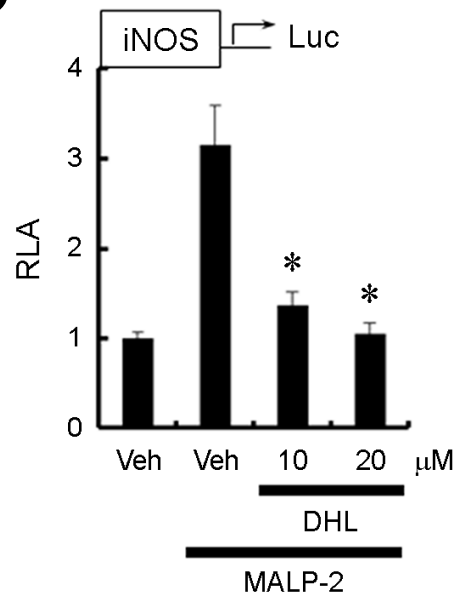

C

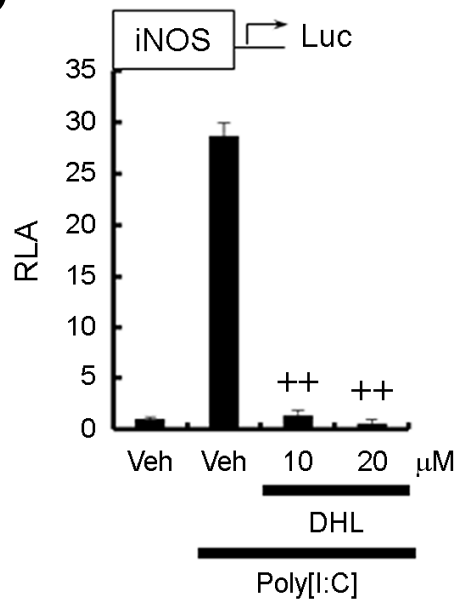

Fig. 3. Dehydrocostus lactone inhibits iNOS expression induced by TLRs agonists. (A-C) RAW264.7 cells were transfected with iNOS luciferase reporter plasmid and pretreated with 10 or $20 \mu \mathrm{M}$ DHL for $1 \mathrm{~h}$ and then treated with LPS (10 ng/mL) (A), MALP-2 (10 ng/mL) (B), or Poly[I:C] $(10 \mu \mathrm{g} / \mathrm{mL})(\mathrm{C})$ for an additional $8 \mathrm{~h}$. Cell lysates were prepared and luciferase enzyme activities were determined. Values represent the mean \pm SEM $(\mathrm{n}=3)$. \#, Significantly different from LPS alone, $P<0.01$ (\#\#) (A). *, Significantly different from MALP-2 alone, $P<0.05$ (*) (B). +, Significantly different from Poly[I:C] alone, $P<0.01(++)($ C). Veh, vehicle; DHL, dehydrocostus lactone: RLA, relative luciferase activity.

A

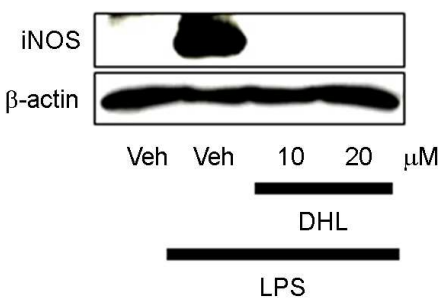

B

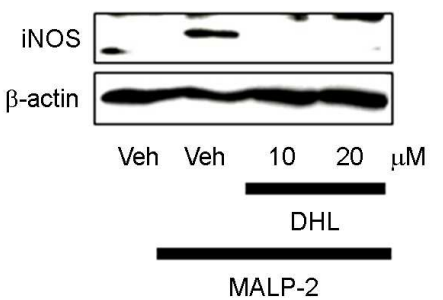

C

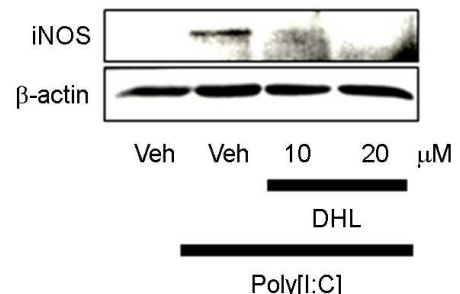

Fig. 4. Dehydrocostus lactone inhibits iNOS protein induced by TLRs agonists. (A-C) RAW264.7 cells were pretreated with 10 or $20 \mu \mathrm{M}$ DHL for $1 \mathrm{~h}$ and then further stimulated with LPS $(10 \mathrm{ng} / \mathrm{mL})(\mathrm{A})$, MALP-2 $(10 \mathrm{ng} / \mathrm{mL})(B)$, or Poly[I:C] $(10 \mu \mathrm{g} / \mathrm{mL})(\mathrm{C})$ for an additional $8 \mathrm{~h}$. Cell lysates were analyzed for iNOS and $\beta$-actin protein by immunoblots. Veh, vehicle; DHL, dehydrocostus lactone. 

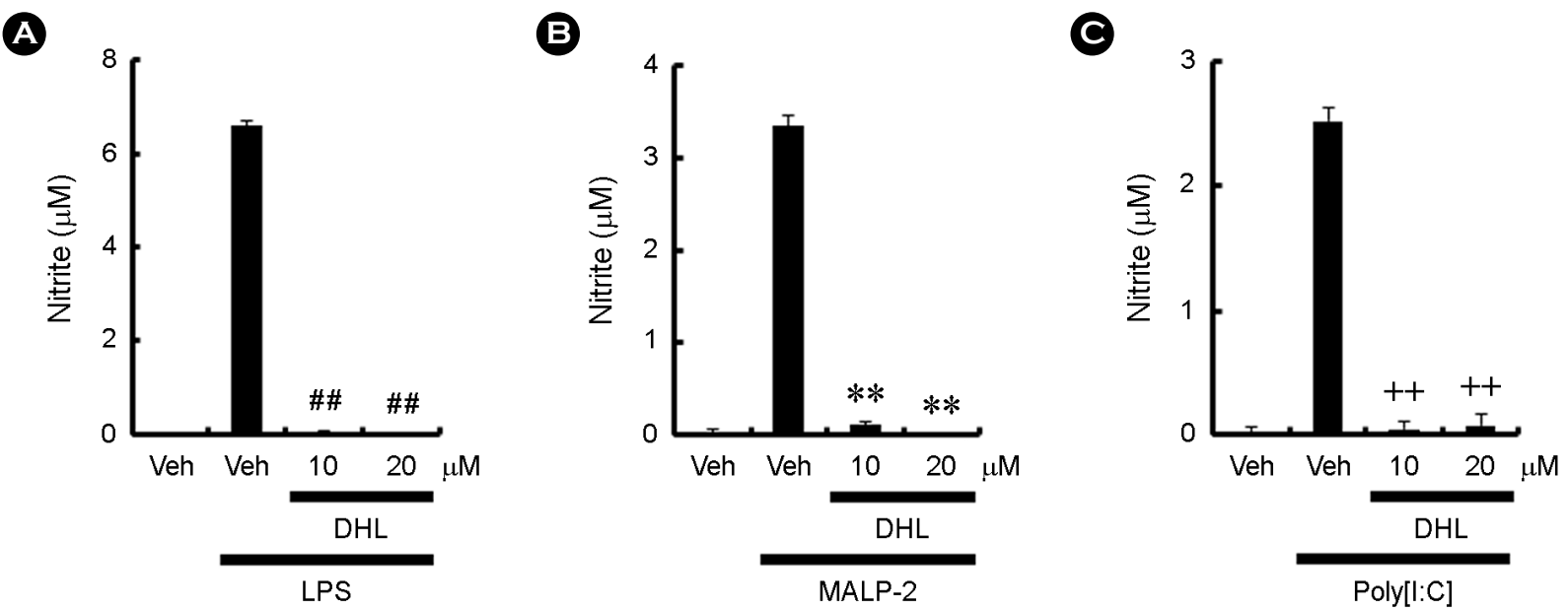

Fig. 5. Dehydrocostus lactone inhibits nitrite production induced by TLRs agonists. (A-C) RAW 264.7 cells were pretreated with 10 or $20 \mu \mathrm{M}$ DHL for $1 \mathrm{~h}$ and then treated with LPS (10 ng/mL) (A), MALP-2 (10 ng/ml) (B), or Poly[I:C] $(10 \mu \mathrm{g} / \mathrm{mL})(\mathrm{C})$ for an additional $20 \mathrm{~h}$. The amounts of nitrite in supernatant were measured using Griess reagent. Values represent the mean \pm SEM $(n=3)$. \#, Significantly different from LPS alone, $P<0.01$ (\#\#) (A). *, Significantly different from MALP-2 alone, $P<0.01$ (**) (B). +, Significantly different from Poly[I:C] alone, $P<0.01(++)(\mathrm{C})$. Veh, vehicle; DHL, dehydrocostus lactone.

플라즈마 막과 연관되어 있다. 질소산화물 3 (NOS3)이라 고도 하는 endothelial NOS (eNOS)는 혈관에 NO를 발생시 키며 혈관 기능을 조절하는 데 관여한다. 혈관 내피에서 eNOS에 의해 생성된 NO는 혈관 색조(vascular tone), 세포 증식(cellular proliferation), 백혈구 부착(leukocyte adhesion), 및 혈소판 응집(platelet aggregation)을 조절하는데 중요 한 역할을 한다(Forstermann and Munzel, 2006). 그러므로 $\mathrm{eNOS}$ 는 건강한 심혈관을 유지하기 위하여 필수적인 요소 이다(Lind et al., 2017).

구성 $\mathrm{NOS}$ 인 $\mathrm{nNOS}$ 및 $\mathrm{eNOS}$ 와 다르게, $\mathrm{iNOS}$ 는 다양한 생리학적 조건(혈압 조절, 상처 치유, 호스트 방어 메커니 즘 등)과 병리생리학(염증, 감염, 신가소성 질환, 간경화증, 당뇨병 등)에서 중요한 역할을 담당한다(Lechner et al., 2005). iNOS는 nitric oxide (NO)를 생성하고, 생성된 NO는 세포 독성 효과가 있어 이와 관련된 염증 및 질병을 유도 하는 것으로 알려져 있다(Vallance, 2003) iNOS는 NF-kB 경로를 통한 염증성 cytokines에 의해 유도되는 것으로 알 려져 있다. Gochman et al. (2012)은 NF-kB가 대장염에 관여 하는 것을 조사할 때, 인체 대장염 조직에서 iNOS 발현 이 증가함을 입증하여 염증성 질환에 대한 기여와, 가능 한 치료법으로서 $\mathrm{iNOS}$ 의 억제를 제안하였다(Gochman et al., 2012). iNOS 유전자를 없앤 마우스에서 대동맥과 중원 동맥(mesenteric arteries)에 대한 박테리아 lipopolysaccharide 의 영향을 평가할 때, Chauhan et al. 등은 lipopolysaccharide
에 의해 유도된 내피 기능 장애(endothelial dysfunction)가 iNOS 유도에 의지한다는 것을 입증하였다(Chauhan et al., 2003). Mungrue et al. 연구진은 마우스 모델의 심근세포에 서 iNOS의 과발현은 서맥성 부정맥(bradyarrythmia), 심근 병(cardiomyopathy) 및 갑작스런 심장사망과 관련이 있다 고 제안하였다(Mungrue et al., 2002). 따라서, 이러한 연구 들에서 보여지는 증거는 염증 기간 동안 iNOS가 질병의 손상 효과에 기여하므로, $\mathrm{iNOS}$ 억제가 질병 예방에 효과 가 있다는 것을 보여주는 결과이다.

선천성 면역체계는 병원균에 대한 숙주의 빠른 반응이 다. 대식세포, 자연살인세포 등 선천성 면역체계를 유도 하는 세포들은 pattern recognition receptor (PRR)를 이용하 여 병원균과 관련된 PAMPs를 인식한다(Medzhitov, 2001). PRR 역할을 하는 대표적인 수용체가 TLRs이다. TLRs는 일반적으로 $\mathrm{MyD} 88$ 과 TRIF에 의지한 두개의 신호전달체 계를 가지고 있다(Fitzgerald et al., 2003; Hultmark, 1994). $\mathrm{MyD} 88$ 은 TLR3를 제외한 모든 포유동물에서 발견되는 TLRs의 TIR (Toll/IL-1R) 도메인에 붙는 즉각적인 어댑터 (adaptor) 분자이며, 전사요소 NF-kB의 활성화를 유도한다. $\mathrm{MyD} 88$ 신호전달체계를 통한 NF-kB 활성은 cytokines 등 염증 유도 물질들의 발현을 증가시켜 다양한 질병을 유발 하는 것으로 알려져 있다(Takeda and Akira, 2005).

한편, TLR3의 활성은 MyD88 대신에 어댑터 분자인 $\mathrm{TRIF}$ 를 의지한 신호전달체계를 통하여 전사인자 IRF3의 
활성화를 유도한다(Fitzgerald et al., 2003). TLR4는 MyD88 과 TRIF를 의지한 양쪽 신호전달체계를 활용한다. 활성화 된 IRF3는 type I IFN 유전자들의 발현을 유도한다(Sato et al., 2003).

따라서 병원균들이 숙주 안으로 들어오면 TLRs가 PAMPs을 인식하여 MyD88 또는 TRIF를 의지한 신호전 달체계를 활용하여 신호를 아래로 전달하고, 여러 단백질 들의 활성화를 통해 cytokines 등 염증 유전자 물질들의 발현을 증가시키지만, 숙주는 후천성 면역반응을 활성화 시켜 여러 질병으로부터 숙주를 보호하는 것으로 알려져 있다. 하지만 계속된 PAMPs의 자극에 의해 숙주의 면역 시스템에 과부하가 걸리게 되면, 오히려 염증 유도 물질 들에 의해 각종 질병이 발생되게 된다. 그러므로, PAMPs 에 의해 유도된 TLRs의 신호전달체계의 활성을 억제하는 것은 만성 염증과 같은 여러 질병을 예방하는 데 있어 매 우 중요하다고 할 수 있다(Takeda and Akira, 2005).

오랜 역사를 가지고 있는 전통 한의학에 따르면 3,000 여 종의 식물이 암 치료에 효과적으로 알려져 있다. 이전 의 연구에 따르면 DHL은 항염증(Cho et al., 2000), 항우 울제(Yoshikawa et al., 1993), 면역조절(Pandey et al., 2007), 및 항암(Ko et al., 2004) 효과를 가지고 있다. 최근에는 백 혈병(Butturini et al., 2011), 폐암(Hung et al., 2010), 유방암 (Pitchai et al., 2014), 간암(Hsu et al., 2009), 난소암(Sun et al., 2003), 전립샘암(Kim et al., 2012), 방광암(Rasul et al., 2013), 대장암(Sun et al., 2015) 등 다양한 종류의 암에 대한 DHL 의 잠재적인 항암 활동으로 인해 연구원들에게 매우 높 은 관심을 불러일으켰다. 그러나 $\mathrm{DHL}$ 의 정확한 항염증. 항암 효과와 작용기전이 아직 설명되지 않았으며, $\mathrm{DHL}$ 의 표적 단백질이 충분히 규명되지는 않고 있다.

본 연구에서는 $\mathrm{DHL}$ 의 항염증 효능을 규명하기 위하여 TLRs 자극제인 LPS, MALP-2, 그리고 Poly[I:C]에 의해 유 도된 $\mathrm{iNOS}$ 의 발현에 미치는 영향에 대해 확인하였다. $\mathrm{DHL}$ 은 TLRs의 MyD88를 의지한 신호전달체계 자극제인 MALP-2 (TLR2 and TLR6 agonist)에 의해서 유도된 iNOS 의 과발현을 억제하였다. DHL은 TLRs의 TRIF를 의지한 신호전달 자극제인 Poly[I:C] (TLR3 agonist)에 의해서 유도 된 $\mathrm{iNOS}$ 의 과발현을 억제하였다. 또한 DHL은 TLRs의 $\mathrm{MyD} 88$ 과 TRIF 양쪽 신호전달체계를 사용하는 LPS (TLR4 agonist)에 의해 유도된 iNOS의 과발현을 억제하였다. 이 러한 결과는 $\mathrm{DHL}$ 이 TLRs의 MyD88과 TRIF 양쪽 신호전 달체계를 조절할 수 있다는 것을 보여주는 결과이다. 따 라서 본 연구의 결과는 DHL이 TLRs의 신호전달체계를
조절하여 다양한 만성질환 치료 및 치료제 개발에 있어서 중요한 역할을 할 것으로 기대된다.

\section{ACKNOWLEDGEMENT}

본 연구는 순천향대학교 학술연구비의 일부 지원과 2017년도 한국연구재단의 지원을 받아 수행된 기초연구 사업(2017R1D1A1B03031534)의 지원을 받아 수행된 연구 결과물로 그 지원에 감사드립니다.

\section{CONFLICT OF INTEREST}

No potential conflict of interest relevant to this article was reported.

\section{REFERENCES}

Akira S, Takeda K. Toll-like receptor signalling. Nat Rev Immunol. 2004. 4: 499-511.

Anderson KV, Bokla L, Nusslein-Volhard C. Establishment of dorsal-ventral polarity in the Drosophila embryo: the induction of polarity by the Toll gene product. Cell. 1985. 42: 791-798.

Asea A, Rehli M, Kabingu E, Boch JA, Bare O, Auron PE, Stevenson MA, Calderwood SK. Novel signal transduction pathway utilized by extracellular HSP70: role of toll-like receptor (TLR) 2 and TLR4. J Biol Chem. 2002. 277: 15028 -15034 .

Butturini E, Cavalieri E, de Prati AC, Darra E, Rigo A, Shoji K, Murayama N, Yamazaki H, Watanabe Y, Suzuki H, et al. Two naturally occurring terpenes, dehydrocostuslactone and costunolide, decrease intracellular GSH content and inhibit STAT3 activation. PLoS One. 2011. 6: e20174.

Chauhan SD, Seggara G, Vo PA, Macallister RJ, Hobbs AJ, Ahluwalia A. Protection against lipopolysaccharide-induced endothelial dysfunction in resistance and conduit vasculature of iNOS knockout mice. FASEB J. 2003. 17: 773-775.

Cho JY, Baik KU, Jung JH, Park MH. In vitro anti-inflammatory effects of cynaropicrin, a sesquiterpene lactone, from Saussurea lappa. Eur J Pharmacol. 2000. 398: 399-407.

Fitzgerald KA, McWhirter SM, Faia KL, Rowe DC, Latz E, Golenbock DT, Coyle AJ, Liao SM, Maniatis T. IKKepsilon and TBK1 are essential components of the IRF3 signaling pathway. Nat Immunol. 2003. 4: 491-496.

Forstermann U, Munzel T. Endothelial nitric oxide synthase in vascular disease: from marvel to menace. Circulation. 2006 113: $1708-1714$ 
Gochman E, Mahajna J, Shenzer P, Dahan A, Blatt A, Elyakim R, Reznick AZ. The expression of iNOS and nitrotyrosine in colitis and colon cancer in humans. Acta Histochem. 2012. 114: 827-835.

Hsu YL, Wu LY, Kuo PL. Dehydrocostuslactone, a medicinal plantderived sesquiterpene lactone, induces apoptosis coupled to endoplasmic reticulum stress in liver cancer cells. J Pharmacol Exp Ther. 2009. 329: 808-819.

Hultmark D. Macrophage differentiation marker MyD88 is a member of the Toll/IL-1 receptor family. Biochem Biophys Res Commun. 1994. 199: 144-146.

Hung JY, Hsu YL, Ni WC, Tsai YM, Yang CJ, Kuo PL, Huang MS. Oxidative and endoplasmic reticulum stress signaling are involved in dehydrocostuslactone-mediated apoptosis in human non-small cell lung cancer cells. Lung Cancer. 2010. 68: 355-365.

Kawai T, Akira S. The role of pattern-recognition receptors in innate immunity: update on Toll-like receptors. Nat Immunol. 2010. 11: 373-384

Kepp O, Galluzzi L, Martins I, Schlemmer F, Adjemian S, Michaud M, Sukkurwala AQ, Menger L, Zitvogel L, Kroemer G. Molecular determinants of immunogenic cell death elicited by anticancer chemotherapy. Cancer Metastasis Rev. 2011. 30: 61-69.

Kim AY, Shim HJ, Kim SY, Heo S, Youn HS. Differential regulation of MyD88- and TRIF-dependent signaling pathways of Tolllike receptors by cardamonin. Int Immunopharmacol. 2018a. 64: 1-9.

Kim AY, Shim HJ, Shin HM, Lee YJ, Nam H, Kim SY, Youn HS. Andrographolide suppresses TRIF-dependent signaling of tolllike receptors by targeting TBK1. Int Immunopharmacol. 2018b. 57: 172-180.

Kim EJ, Hong JE, Lim SS, Kwon GT, Kim J, Kim JS, Lee KW, Park JH. The hexane extract of Saussurea lappa and its active principle, dehydrocostus lactone, inhibit prostate cancer cell migration. J Med Food. 2012. 15: 24-32.

Knowles RG. Nitric oxide synthases. Biochem Soc Trans. 1996. 24: 875-878.

Ko SG, Koh SH, Jun CY, Nam CG, Bae HS, Shin MK. Induction of apoptosis by Saussurea lappa and Pharbitis nil on AGS gastric cancer cells. Biol Pharm Bull. 2004. 27: 1604-1610.

Lechner M, Lirk P, Rieder J. Inducible nitric oxide synthase (iNOS) in tumor biology: the two sides of the same coin. Semin Cancer Biol. 2005. 15: 277-289.

Lim HJ, Lee HS, Ryu JH. Suppression of inducible nitric oxide synthase and cyclooxygenase-2 expression by tussilagone from
Farfarae flos in BV-2 microglial cells. Arch Pharm Res. 2008. 31: 645-652.

Lind M, Hayes A, Caprnda M, Petrovic D, Rodrigo L, Kruzliak P, Zulli A. Inducible nitric oxide synthase: Good or bad? Biomed Pharmacother. 2017. 93: 370-375.

Lowenstein CJ, Padalko E. iNOS (NOS2) at a glance. J Cell Sci. 2004. 117: 2865-2867.

Medzhitov R. Toll-like receptors and innate immunity. Nat Rev Immunol. 2001. 1: 135-145.

Medzhitov R, Preston-Hurlburt P, Janeway CA, Jr. A human homologue of the Drosophila Toll protein signals activation of adaptive immunity. Nature. 1997. 388: 394-397.

Mungrue IN, Gros R, You X, Pirani A, Azad A, Csont T, Schulz R, Butany J, Stewart DJ, Husain M. Cardiomyocyte overexpression of iNOS in mice results in peroxynitrite generation, heart block, and sudden death. J Clin Invest. 2002. 109: 735-743.

Murakami A, Ohigashi H. Targeting NOX, INOS and COX-2 in inflammatory cells: chemoprevention using food phytochemicals. Int J Cancer. 2007. 121: 2357-2363.

Pandey MM, Rastogi S, Rawat AK. Saussurea costus: botanical, chemical and pharmacological review of an ayurvedic medicinal plant. J Ethnopharmacol. 2007. 110: 379-390.

Pitchai D, Roy A, Banu S. In vitro and in silico evaluation of NFkappaB targeted costunolide action on estrogen receptornegative breast cancer cells--a comparison with normal breast cells. Phytother Res. 2014. 28: 1499-1505.

Poltorak A, He X, Smirnova I, Liu MY, Van Huffel C, Du X, Birdwell D, Alejos E, Silva M, Galanos C, et al. Defective LPS signaling in $\mathrm{C} 3 \mathrm{H} / \mathrm{HeJ}$ and $\mathrm{C} 57 \mathrm{BL} / 10 \mathrm{ScCr}$ mice: mutations in Tlr4 gene. Science. 1998. 282: 2085-2088.

Rasul A, Bao R, Malhi M, Zhao B, Tsuji I, Li J, Li X. Induction of apoptosis by costunolide in bladder cancer cells is mediated through ROS generation and mitochondrial dysfunction. Molec ules. 2013. 18: 1418-1433.

Sato S, Sugiyama M, Yamamoto M, Watanabe Y, Kawai T, Takeda K, Akira S. Toll/IL-1 receptor domain-containing adaptor inducing IFN-beta (TRIF) associates with TNF receptorassociated factor 6 and TANK-binding kinase 1, and activates two distinct transcription factors, NF-kappa B and IFNregulatory factor-3, in the Toll-like receptor signaling. $\mathrm{J}$ Immunol. 2003. 171: 4304-4310.

Sun CM, Syu WJ, Don MJ, Lu JJ, Lee GH. Cytotoxic sesquiterpene lactones from the root of Saussurea lappa. J Nat Prod. 2003. 66: $1175-1180$

Sun X, Kang H, Yao Y, Chen H, Sun L, An W, Jiang E, Wang S, 
Hu X. Dehydrocostus lactone suppressed the proliferation, migration, and invasion of colorectal carcinoma through the downregulation of eIF4E expression. Anticancer Drugs. 2015. 26: 641-648.

Takeda K, Akira S. Toll-like receptors in innate immunity. Int Immunol. 2005. 17: 1-14.

Vallance P. Nitric oxide: therapeutic opportunities. Fundam Clin Pharmacol. 2003. 17: 1-10.

Yoshikawa M, Hatakeyama S, Inoue Y, Yamahara J. Saussureamines $\mathrm{A}, \mathrm{B}, \mathrm{C}, \mathrm{D}$, and $\mathrm{E}$, new anti-ulcer principles from Chinese Saussureae Radix. Chem Pharm Bull (Tokyo). 1993. 41: 214 -216 .

Youn HS, Lee JY, Saitoh SI, Miyake K, Hwang DH. Auranofin, as an anti-rheumatic gold compound, suppresses LPS-induced homodimerization of TLR4. Biochem Biophys Res Commun. 2006a. 350: 866-871.

Youn HS, Lee JY, Saitoh SI, Miyake K, Kang KW, Choi YJ, Hwang DH. Suppression of MyD88- and TRIF-dependent signaling pathways of Toll-like receptor by (-)-epigallocatechin -3-gallate, a polyphenol component of green tea. Biochem Pharmacol. 2006b. 72: 850-859.

https://doi.org/10.15616/BSL.2019.25.3.267

Cite this article as: Kim SY, Heo S, Kim SH, Kwon M, Park SA, Youn HS. Dehydrocostus Lactone Suppresses the Expression of iNOS Induced by TLR Agonists. Biomedical Science Letters. 2019. 25: 267-274. 